\title{
ECONOMICAL AND SOCIAL IMPACTS OF TOURISM SEASONALITY- AN APPLIED STUDY ON SHARM EL-SHEIKH
}

\author{
By \\ Dina Hassan El- Rady Saad
}

Master Researcher

Faculty of Tourism and Hotels - Mansoura University

Dr/Rania Mohamed Bahaa ElDin

Ass. Prof of Tourism management-

Faculty of Tourism and Hotels -

Mansoura University
Prof/Soha Mohamed Abd Elwahab Prof of Tourism managementFaculty of Tourism and Hotels Helwan University

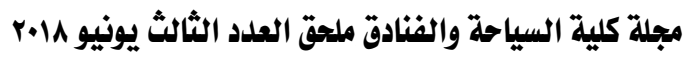

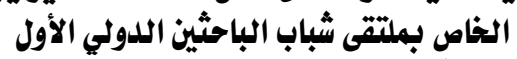

$$
\begin{aligned}
& \text { (التراث الحضاري و مستقبل السياحة في مصر) }
\end{aligned}
$$




\section{ECONOMICAL AND SOCIAL IMPACTS OF TOURISM SEASONALITY- AN APPLIED STUDY ON SHARM EL-SHEIKH}

\author{
Dina Hassan El- Rady \\ Saad ${ }^{1}$
}

\author{
Dr/Rania Mohamed Bahaa \\ ElDin $^{2}$
}

\author{
Prof/Soha Mohamed Abd \\ Elwahab ${ }^{3}$
}

\section{Abstract}

Seasonality is a concept that is well studied and documented in the tourism literature. Seasonality causes the fluctuation in tourist and visitor numbers to a destination.

Sharm El-Sheikh is distinguished with its dramatic landscape, it contains a variety in the marine life species and lots of companies have been attracted to invest in Sharm.

This paper aims to identify the economical, environmental and sociocultural effects of tourism seasonality in Sharm el-Sheikh, also it aims to suggest techniques to overcome seasonality or reduce its impacts.

To achieve these objects, two types of questionnaire have been used as follow: sales manager questionnaire and tourism workers questionnaire. They have been distributed to 90 hotels in Sharm EL-Sheikh.

The results of the research indicated that the negative impacts of tourism seasonality exceeded the positive impacts and the Russian Airplane crash was the most impulsive incident on tourism in Sharm El-Sheikh and the sample study gave lots of recommendations and techniques to overcome seasonality.

Key Words: Seasonality, Sharm El-Sheikh, Tourism, Environmental, economical, socio cultural. 


\section{الآثار الإقتصادية والإجتماعية لاوسميهية السياحة-}

\section{دراسة تطبيقية علي شرم الشيهخ}

أصبـحت السياحة علي مدى العقود الماضيـة مـن أكبر وأسـرع القطاعات الإقتصدادية فى . العالم نموا ، وهى من أحد الركائز الرئيسية التي تعتمد عليها إقتصاديات الدول المتقدمـة ِِّوفير فرص عمل ومصدر للدخل القومي.

ومـع سرعة تطور هذا النوع من الصناعة وزيـادة أهميتها واجهت العديد مـن التحديات التي تتعلق بالطلب والعرض السياحي ومن ضهمن هذه التحديات هي موسمية السياحلة، والتي تؤثر مِ جميع الجوانب المالية، الإقتصاديـة، الإجتماعية، العمالة، التسعير، الأنثطة التي تقدمها منطقة

$$
\text { الجذب السياحي وغيرها ... }
$$

وسوف تركز هذه الدراسـة على المشاكل والملامسح الرئيسية لموسمية السياحة يخ منطقة ثـرم الشيخ وآثارها الإقتصدادية والإجتماعية حيث أنها من أكبر مدن محافظة جنوب سيناء،وتضم منتجعات سياحية ترتادها الأفواج السياحيـة من أنحاء العالم. وتشتهر بـالغوص، فهي أحد ثلاث مواقع غوص يخ مصر معروفة عالمياً. ولتحقيق هذه الأهداف ، تم استخدام نوعين من الاستبيانات والذي تم توزيعهم على عدد •ه فندق بشرم الشيخ على النحو التالي: استبيان موجه لملديري المبيعات وآخر موجه للعاملين يِ. مجال السياحة. أثـارت نتائج البحث إلى أن التأثيرات السلبية لموسهية السياحة تجاوزت الآثار الإيجابية وأن حادث تحطم الطائرة الروسية كان أكثر الحوادث السلبيـة المؤثرة على السياحة يخ شرم الشيخخ. كما قدمت عينـة الدراسـة الكثير من التوصيات والتقنيـات للتغلب على الموسمية. الكالمات الدالة : الموسميـة، شرم الشيخ، السياحة، الآثار الإقتصادية، الأثار الإجتماعية الثقافية، الآثار البيئيـة. 
Economical and Social Impacts of Tourism Seasonality

\section{Introduction}

Tourism is a social, cultural and economic phenomenon which entails the movement of people to countries or places outside their usual environment (TFSITS, 2010).

Meanwhile, the tourism industry has undergone a decade of transformation that has influenced each part of it which makes it a very complex industry involving numerous stakeholders and requiring significant amount of resources and learning to include tools for planning and information (www.unep.org).

Due to the nature of the industry, there are always new challenges related to both demand and supply- sides. One of these challenges is seasonality which has been long recognized as an unalienable part of tourism. This phenomenon is mostly recognized as a problem to be tackled in Sharm El-sheikh.

A range of potential positive and negative changes is possible to occur and these must be taken into account in the strategic marketing and planning undertaken by destination managers. These economic, environmental and sociocultural changes are commonly referred to as "impact" issues in the tourism literature. It is, common in the tourism literature to distinguish between economic, sociocultural and environmental impacts however; these impacts are often closely interrelated. For example, negative social reactions to tourism could result from residents' perceptions of accompanying economic and environmental costs (Twining-Ward, 1999).

\section{Aim of the Research:-}

1- Identifying the economic effects of tourism seasonality in Sharm elSheikh.

2- Identifying the socio cultural effects of tourism seasonality in Sharm elSheikh.

3- Identifying the effects of tourism seasonality on the environment of Sharm elSheikh.

4- Suggesting techniques to overcome seasonality or reduce its impact.

\section{Literature of Review}

Nowadays tourism is widespread throughout the world. Millions of people travel to different countries all year round seeking rest, new experience، and impression. Lately tourism has become quite a profitable business, which also brings benefits to a country's economy (Rogers, 2008; Rogers, 2003; Dwyer \& Mistilis, 1999). Tourism has three major impacts 
on the destination which tourists usually visit (Cooper et al. 2008), these are mainly economic, environmental، and socio-cultural in nature.

Seasonality is identified as one of the most visible characteristics of modern tourism, and most destinations experience some kind of seasonal pattern. In general' seasonality means special annual dependence, or ' more precisely "seasonality is the systematic, although not necessarily regular, intra-year movement caused by the changes of the weather, the calendar, and timing of decisions, directly or indirectly through the production and consumption decisions made by the agents of the economy. These decisions are influenced by endowments, the expectations and preferences of the agents, and the production techniques available in the economy" (Hylleberg, 1992,).

Seasonal effects can be grouped into three main categories: economic impacts, socio-cultural impacts and environmental impacts.

Economic impact of tourism seasonality deals with problems in the off peak periods, especially the loss of profits due to the inefficient use of resources and facilities (Sutcliffe and Sinclair, 1980; Manning and Powers, 1984; William and Shaw, 1991). Murphy (1985) argues that businesses and communities need to attain sufficient revenues from a few busy weeks in the summer, in order to ensure success for the whole year. (Mathieson and Wall, 1982).

In the accommodation services, the seasonal fluctuations may cause a shortage of hotel rooms in the peak season and underutilization of facilities in the off-peak season. Seasonality has an important impact on employment (Ball, 1988, 1989; Ashworth and Thomas, 1999; Flognfelt, 2001). The most important issue is the difficulty in recruiting and retaining full-time staff (Yacoumis, 1980) and related to this, there is the difficult to maintain product and quality standards (Baum, 1999).

From another perspective, there are also positive economic effects of seasonality. For instance, maintenance work on buildings or attractions is a typical activity to do in the off-peak periods. Murphy (1985) states that up market hotels in the accommodation sector have been very successful in attaining usage efficiency, because they are open all year round for business and so that they are able to keep their highly skilled staff. On employment sector, seasonality can offer opportunities of temporary jobs to some people, such as students.

Although socio-cultural impacts include effects on both the host community and tourists, the academic literature focuses on impacts relating 
to the local community. During the peak period local people can suffer problems of congestion on traffic, on the access to commercial services, queues for service, and especially in significant increases in the costs of services and goods. As an effect of higher prices, the quality of life can be low (Fitzpatrick Associates, 1993).

Manning and Powers (1984) argue that socio-cultural impacts (e.g. crime, congestion, higher prices) place a strain on the social carrying capacity of the destination, which might result in resentment from the local community towards all tourism activities.

\section{Research Methodology}

As mentioned previously, the aim of the present study is to identify the economical, social and environmental effects of tourism seasonality on Sharm El-sheikh and to suggest techniques to overcome seasonality or reduce its impacts. For this purpose, two questionnaires were designed and applied on 90 hotels and resorts in Sharm El-Sheikh, 75\% of these hotels were five stars in order to gather professional answeres and Excel Program was used to make the statistical analysis:-

- Ninety (90) questionnaires have been distributed to the Hotels Sales Managers in Sharm El Sheikh and (80 out of 90) have given their response so the random sample percentage out of the total was $88.8 \%$.

- Two hundred and seventy (270) questionnaires have been distributed to Tourism workers in Sharm El-sheikh. Three types of workers have been chosen (the receptionist, food and beverage and the public relations) as they face the problems that occur to tourists and more aware of the social and economic problems. (200 out of 270) worker have given their response so the random sample percentage out of the total was $74 \%$.

\section{Results and Discussions:}

\section{First: the sales Managers questionnaire:-}

The findings of the first questionnaire were illustrated in the following data. As seen in figure (1) that represents the months of low season around the year, April is the month that has the lowest number of tourists with a percentage of (62.5\%), followed by March with a percentage of (55\%) and May with a percentage of (52.5\%). This occurred regarding that April and May are connected to the exam months which make no opportunity for people to take a vacation 
مجلة كلية السياحة والفنادق - ملحق العدد الأول يونيو Vا.r الخاص بالمؤتمر العلمي الأول

Figure (1) The Months of the low season around the year

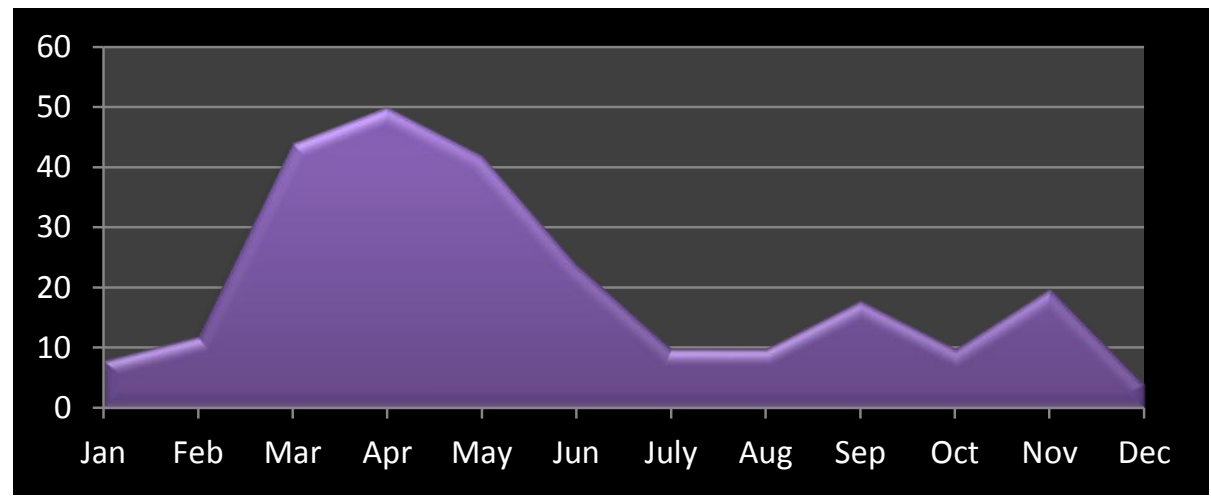

In figure (2) the 80 investigated hotels and resorts in Sharm El-sheikh showed that the majority of the respondents agreed that August is the month that has the highest number of tourists with a percentage of $(82.5 \%)$, followed by July with a percentage of $(72.5 \%)$.

Most of the tourists can take a break from their work at this time of year as July and August are considered the holiday for the students around the world. It is noticed that in December (20\%), January (27.5\%) and February (20\%) the weather is moderate which attracts tourists from cold countries to enjoy sharm's sun, also the new year vacation for international tourists motivate them to travel around the world.

Figure (2) The Months of the High season around the year

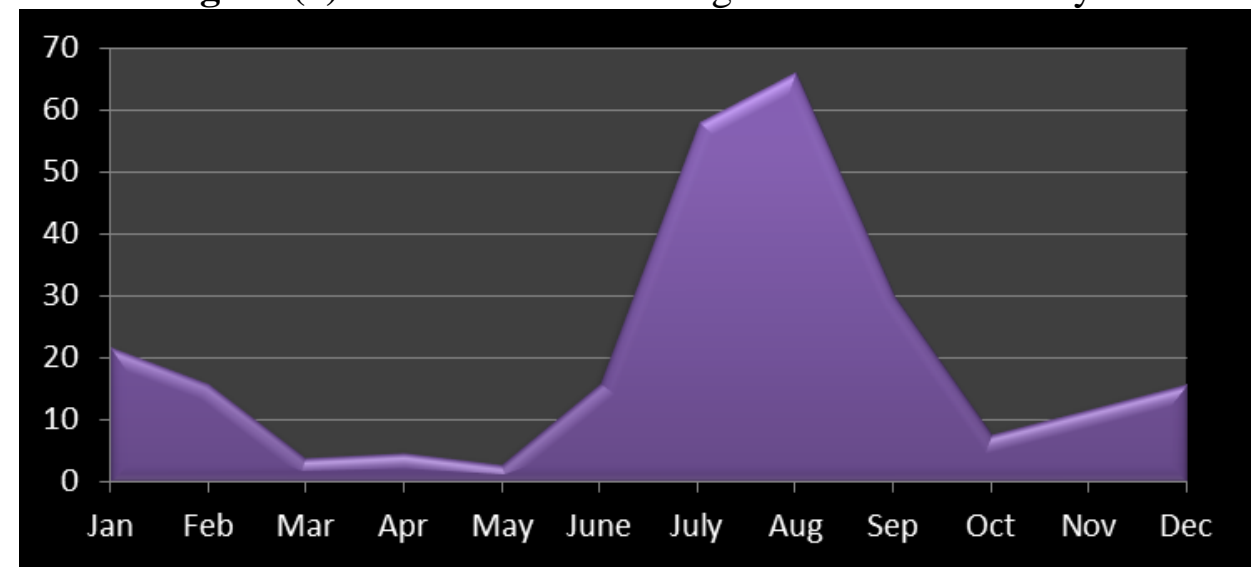

Table (1) showed that the majority of the respondents agreed that the Arab's Nationalities are the highest targets for the hotels and resorts of Sharm ElSheikh with a percentage of $(80 \%)$. 
The Arab Gulf suffers from the high temperature in summer season which can reach to 50 degree or more. So they escape to places like Sharm ElSheikh to enjoy its moderate weather which is about 35 degree. That's the main reason why the Arab's achieves the highest percentage in low season than the Egyptians and foreigners.

Table (1) Targeted Markets in Low season

\begin{tabular}{|c|c|c|c|}
\hline \multirow{2}{*}{ Factor } & Variables & Frequency & Percentage (\%) \\
\hline \multirow{3}{*}{ Targeted } & Arab & 64 & $80 \%$ \\
\cline { 2 - 4 } Markets in & Italian & 16 & $20 \%$ \\
\cline { 2 - 4 } & Russian & 0 & $0 \%$ \\
\cline { 2 - 4 } Low Season & French & 0 & $0 \%$ \\
\cline { 2 - 4 } & Egypt & 8 & $10 \%$ \\
\cline { 2 - 4 } & Other & 24 & $30 \%$ \\
\hline \multicolumn{2}{|c|}{ Total } & 112 & $140 \%$ \\
\hline
\end{tabular}

In table (2) seventy five percent (75\%) of the managers who responded on the questionnaire indicated that the major negative impacts of seasonality is economically .

Economic impacts can be shown easily by numbers and statistics which make it the fastest not only in appearance but also in affecting the touristic projects.

Table (2) Major Negative impacts of Seasonality

\begin{tabular}{|c|c|c|c|}
\hline Factor & Variables & Frequency & $\begin{array}{c}\text { Percentage } \\
(\%)\end{array}$ \\
\hline \multirow{3}{*}{$\begin{array}{c}\text { Major } \\
\text { Negative } \\
\text { impacts of } \\
\text { Seasonality }\end{array}$} & $\begin{array}{c}\text { Economic } \\
\text { impacts }\end{array}$ & 60 & $75 \%$ \\
\hline & $\begin{array}{l}\text { Employment } \\
\text { impacts }\end{array}$ & 36 & $45 \%$ \\
\hline & $\begin{array}{c}\text { Ecological } \\
\text { impacts }\end{array}$ & 4 & $5 \%$ \\
\hline \multicolumn{2}{|c|}{ Total } & 104 & $130 \%$ \\
\hline
\end{tabular}

Figure (3) shows that most of the respondents said that the Russian Airplane crash is the most negative event that led to a huge decrease in the number of tourists $(56 \%)$ followed by political issues $(35 \%)$. 
It is concluded that the Russian Airplane Crash was the most negative event that affected tourism in Sharm El-Sheikh. These accidents happen all over the world and give the same impact but it is the responsibility of the state to enhance and overcome the negative impacts in short terms.

Figure (3) Negative events

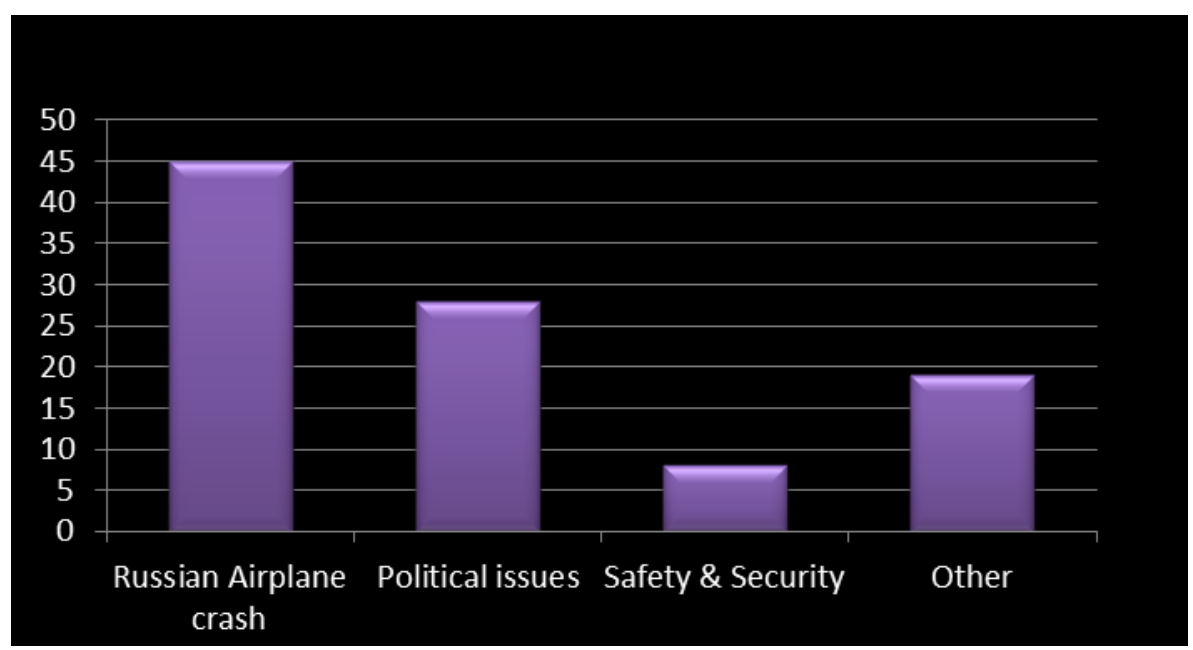

Eighty percent of the owners and managers of the Hotels and Resorts reported that there are some policies and strategies to be followed in case of the low and high seasons to attract more tourists

Most of the policies that are set during the low season for most of the hotels and resorts are ranged in the following:

- Saving and reducing the costs

- Improving online system to attract different markets

- All-inclusive offers

- Lowing rates

- Contracting with Booking.com in setting the prices and the propaganda.

While the policies that are set during the high season for most of the hotels and resorts are ranged in the following:-

- Increasing the rooms' rates

- Hiring more qualified staff

- Stopping sale for local markets

The above suggested policies can help in both low and high season except the policy of reducing room costs in low season as it can attract a low 
income tourist with low social habits which can affect negatively on the hotel and the workers.

Meanwhile, although there are some policies to be followed but the majority of the respondents agreed that there are no positive impacts of seasonality with a percentage of $(62.5 \%)$. The rest of the respondents $(37.5 \%)$ said that there are positive impacts as in low season they have the ability to be trained more by the hotel manager which increases there expertise and make them more professional. This kind of training helps them to get promoted in their work very fast which increases their wages afterwards

So, another question was presented to target if there is a united policy among the hotels and resorts in all of Sharm El-Sheikh to help each other in case of low attraction of tourists, but $85 \%$ of the random sample showed that there isn't almost any Corporate Responsibility to face seasonality in low season.

Unfortunately, when each hotel is only responsible to achieve its target, this will lead to the closing of several hotels. So a united policy will help maintain the prosperity of entire Sharm El-Sheikh

While a united policy is very essential to overcome seasonality, also studying the experiences of competing countries to overcome seasonality can be very helpful. Unfortunately $75 \%$ said that there is no previous studied cases have been applied in Sharm El-Sheikh.

Second: the tourism workers questionnaire:-

The findings of the second questionnaire were illustrated in the following data.

From the 200 gathered answers, it was shown that single people tend to work in tourism more than the married ones with a percentage of $60 \%$ as he/she has the opportunity to work away from home for several months and can tolerate with the low wages sometimes.

Their monthly income ranged from 1000:3000 L.E was shown with a percentage of $(57.5 \%)$ followed by more than 3000 L.E with a percentage of (23.5\%) and only (19\%) of the respondents were below 1000 L.E.

The range from 1000: 3000 L.E per month in Egypt is considered to be a good wage to live by. Meanwhile, workers do not only rely on their monthly wage but also on the tips provided by the guests for the food and beverage section. Not to mention, most of the workers work from 8 to 10 hours per day so they eat at the hotel as well. 
This random study sample, expressed from their point of view the negative and positive impacts of tourism seasonality as $67 \%$ of the distributed questionnaires showed that the tourism worker's opinions are not taken in consideration:-

- The positive impacts of seasonality especially in the low season are: renovation of the resorts, having enough time for the workers to be trained, provide many job opportunities and reducing the loss percentage.

- The negative impacts of seasonality especially in the low season are: the salary is not stable and the revenues of the resort are not as expected, so unfortunately the owners of the resorts target a lower level of tourists which will have bad and negative influence not only on the organization but also on the workers.

The study sample also said that they suffered from instability in their social life, because in the low season the worker is exposed to be fired by the organization due to the decrease in the number of tourists.

It is also noted that the worker's answers targeted only the low season as they suffer socially and economically in the off season more than any other season.

On the other hand, the same question of the negative events affecting the tourism sector was mentioned too in the tourism worker's questionnaire and it showed that the Russian Airplane Crash is the most negative event that led to a decrease in the number of tourists with a percentage of $(52.5 \%)$ which is the same answer to the sales manager questionnaire with a percentage of $(45 \%)$.

Finally, table (3) showed that attracting new markets and targeting the outdoor publicity were the two main answers for most of the sample. It is shown that these two answers can help raise the number of guests so it is considered to be internal procedure

Table (3) ways to overcome seasonality

\begin{tabular}{|c|c|c|c|}
\hline Factor & Variables & Frequency & Percentage $(\%)$ \\
\hline \multirow{3}{*}{$\begin{array}{l}\text { From your } \\
\text { point of view, } \\
\text { how can we } \\
\text { overcome }\end{array}$} & Attract new markets & 60 & $30 \%$ \\
\hline & $\begin{array}{c}\text { United policy among } \\
\text { hotels }\end{array}$ & 30 & $15 \%$ \\
\hline & $\begin{array}{l}\text { Take the opinions of } \\
\text { the workers }\end{array}$ & 70 & $35 \%$ \\
\hline
\end{tabular}


Economical and Social Impacts of Tourism Seasonality

\begin{tabular}{|c|c|c|c|}
\hline seasonality? & $\begin{array}{c}\text { Policies provided by } \\
\text { the state }\end{array}$ & 20 & $10 \%$ \\
\cline { 2 - 4 } & $\begin{array}{c}\text { Focus on the external } \\
\text { media }\end{array}$ & 65 & $32.5 \%$ \\
\hline & Total & 245 & $122.5 \%$ \\
\hline
\end{tabular}

\section{Conclusion}

Before year 2010, the numbers of tourists were high in all the months of the year; the only difference was in the nationality of the tourists during the months. Also the type of the tourist was very rich and the level of the tourist's character was very elegant .

After the Egyptian revolution, tourism in Sharm El-Sheikh was highly seasonal. This poses difficulties for the directors of tourist service enterprises and particularly affects the management of human resources, which has an impact on the quality of service and the organization image. At the same time, the fall in profits due to the inability to optimize the use of resources and capabilities during the less active periods, has a negative impact on regional economic development.

Seasonality is a temporal imbalance in which have various impacts on the economic, socio cultural and environmental categories.

In the economic category, it can be seen in the number of tourists around the year as the low season was shown in April and May regarding the exam's months which make no opportunity for the people to take a vacation.

Meanwhile, the high season was noticed to be in July and August due to the holiday season around the world. Also in December, January and February the weather is moderate which attracts tourists from cold countries to enjoy Sharm's sun.

Seasonal variations are part of the normal annual tourism cycle of a destination which brings a large amount of economic and social corruption which makes the negative impacts overcome the positive impacts.

One of the incidents that affected not only Sharm El-sheikh as a touristic place but also the workers and people live there was the Russian Airplane crash. Unfortunately, Sharm El-sheikh doesn't apply a united policy for all the hotels to help each other in case of low attraction of tourists which make it vulnerable and exposed to lots of losses.

In the socio cultural category, the negative impacts were more obvious than the positive ones as most of the workers complained from the salary 


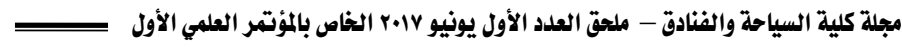

instability and being exposed to be fired at any time due to the low demand on the hotel.

Also in high season, the workers suffer from too many working hours which make them very exhausted most of the time.

From the bright side, there were some positive impacts as in low season they have the ability to be trained more by the hotel managers which increase there expertise and make them more professional. This kind of training helps them to get promoted in their work very fast which increases their wages afterwards.

\section{Recommendations}

Based upon both the literature reviewed and the field study findings, the following recommendations could be suggested:

- New markets must be targeted and these markets must be chosen on specific categories like having high income to have the ability to spend hard currency in Sharm El-sheikh Application of the correct food safety practices during the food handling procedures to ensure the quality of food served.

- Use the media force and its influence in making a good internal and external propaganda of Sharm's facilities and environment.

- Go back to the standard of quality in choosing the guests and their profiles as the aim is not collecting but selecting to preserve the city's high level.

- Full cooperation between the tourism ministry, the Civil Aviation ministry, archaeology ministry and the media to attract tourism again into the region.

- Providing training programs from the ministry and make it obligatory for the workers in the tourism sector to raise the standard of service.

- Opinions of tourism's professionals must be taken into consideration.

- The Tourism Ministry should apply a united strategic plan on the city of Sharm El-Sheikh.

\section{References:}

- Ashworth, J. \& Thomas, B. (1999) Patterns of seasonality in employment in tourism in the UK. Applied Economics Letter, 6 (11): 735-739. 
- Ball, R. M. (1988). Seasonality: a problem for workers in the tourism labour market? Service Industries Journal, 8 (4): 501-513.

- Ball, R. M. (1989). Some aspects of tourism, seasonality and local labour markets. Area, 21 (1): 35-45.

- Baum, T. (1999). Seasonality in tourism: understanding the challenges. Introduction. Tourism Economics, Special Edition on Seasonality in Tourism, 5 (1): 5-8.

- Cooper, C., Fletcher, J., Fyall, A., Gilbert, D. and Wanhill, S. (2008). Tourism Principles and Practice: (4th Edition). Harlow : Financial Times Prentice Hall

- Dwyer, L. and Mistilis, N. (1999). Tourism Gateways and Regional Economies: The Distributional Impacts of MICE. International Journal of Tourism Research, 1(6), 441-457.

- Fitzpatrick Associates (1993). All-Season Tourism: Analysis of Experience, Suitable Products and Clientele. Commission of the European Communities. Directorate-General XXIII - Tourism Unit. Luxembourg .

- Flognfeldt, T. (2001). "Long-Term Positive Adjustments to Seasonality: Consequences of Summer Tourism in the Jotunheimen Area, Norway". In T. Baum \& S. Lundtorp (eds.) Seasonality in Tourism. Oxford: Pergamon.

- Hylleberg, S. (1992). General introduction. In S. Hylleberg (Ed.), Modelling seasonality (pp. 3-14). Oxford: Oxford University Press.

- Manning, R. E. \& Powers, L. A. (1984). Peak and off-peak use: redistributing the outdoor recreation/tourism load. Journal of Travel Research, 23 (2): 25-31.

- Mathieson, A. \& Wall, G. (1982). Tourism. Economic, Physical and Social Impacts. Essex: Longmann.

- Murphy, P. E. (1985). Tourism, A Community Approach. London: Methuen. Nash R. \& Martin A (2003). Tourism in Peripheral Areas - The Challenges for Northeast Scotland, International Journal of Tourism Research, 5, 161-181.

- Price MF/Harrison D 1996: Fragile Environments, Fragile Communities? An Introduction: People and Tourism in Fragile Environemnts, John Wley and Sons Ltd.

- Rogers, T. (2003). Conferences and Conventions - A Global Industry. Oxford: Butterworth Heinemann. 
- Rogers, T. (2008). Conferences and Conventions: A global industry (2nd Edition). Burlington, MA :Elsevier Ltd.

- Sutcliffe, C. M. \& Sinclair, M. T. (1980). The measurement of seasonality within the tourist industry: an application to tourist arrivals in Spain. Applied Economics, 12(4): 429-441.

- Williams, A. M. \& Shaw, G. (1991). Tourism and Economic Development. Western European Experiences ( $2^{\circ}$ ed.). Chichester: Wiley \& Sons.

- Yacoumis, J. (1980). Tackling seasonality. The case of Sri Lanka. International Journal of Tourism Management, 1(2): 84-98.

${ }^{1}$ Master Researcher Faculty of Tourism and Hotels - Mansoura University rAss. Prof of Tourism management- Faculty of Tourism and Hotels - Mansoura University 3Prof of Tourism management- Faculty of Tourism and Hotels - Helwan University 